Animal Health Research Institute, Alex. Lab.

\title{
PREFERENCE OF PATHOGENIC BACTERIAL ASSOCIATED INFERTILITY IN SHEEP WITH SPECIAL REFERENCE TO CAMPYLOBACTER FOETUS AND ITS SENSITIVITY TO SOME ANTIMICROBIAL AGENTS
}

(With 7 Tables and One Figure)

\author{
By \\ A.A. ABDEL-RAHMAN; D.R. DERAR* \\ and E.M. MAGDY** \\ * Fac. of Vet. Med. Assiut University \\ **Animal Health Research El-Minia. Lab \\ (Received at 2/9/2008)
}

مدى تواجد البكتريا الممرضة المصاحبة للعقم فى الأغنام مع الأشـارة الخاصة لميكروب كمبيلوبكتر فيتس وحساسيته لبعض المض المضادات الحيوية المختلفة الإنة

$$
\begin{aligned}
& \text { عبدالرحن عبد/المجبِ عبد/لرحن ، ضرار رفعت /براهيم ، }
\end{aligned}
$$

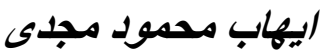

استهدفت الدراسة إلى إلقاء الضؤ على العدوى البكتبرية المسببة للعق فى الأغنام وأجريت

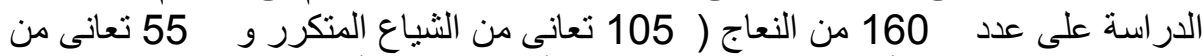

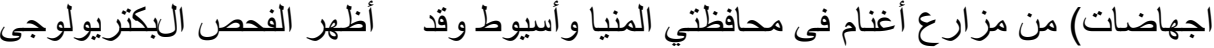

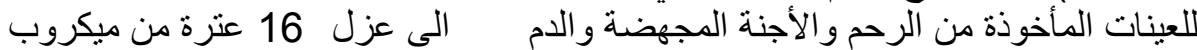

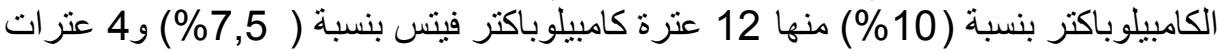

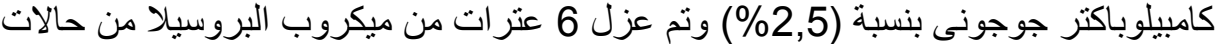

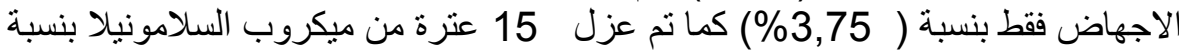

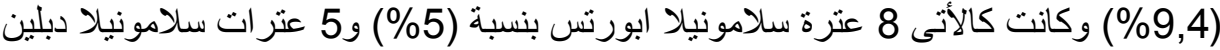

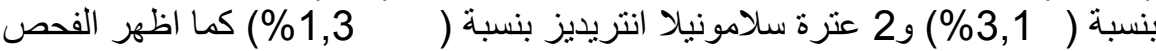

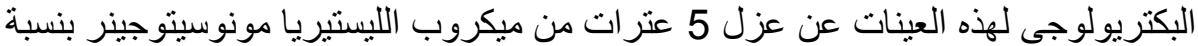

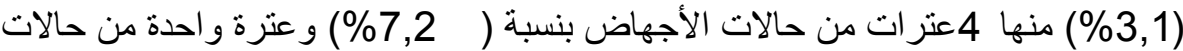

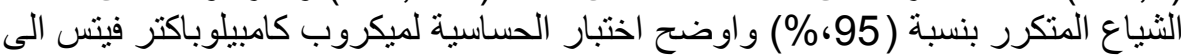

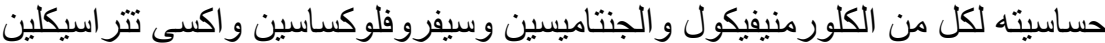

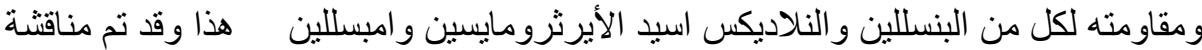
النتائج و الأهمية الصحية للبكتريا المعزولة ومدى خطورتها على الصحئ الصحة العامة.

\section{SUMMERY}


A total of 160 ewes were examined in present study having a history of infertility (55 abortions, and 105 repeat breeders). Samples for bacteriological examination including vaginal swabs, faetal fluid, liver and stomach content of aborted faeti, placenta and blood. All the isolates encountered in this investigation following use of culture on selective media, biochemical reaction and serological tests. A total of $16(10 \%)$ isolates identified as being campylobacter spp. were recovered, of which 12 isolates from abortion cases with incidence of (21.8\%) and 4 isolates from repeat breeder with incidence of (3.8\%). Moreover 12 isolates out of the 16 isolates were identified as $C$. fetus subsp fetus with incidence of $(7.5 \%)$ and 4 isolates as $C$. jejuni with incidence of $(2.5 \%)$. The brucellae isolate was $6(3.75 \%)$ from only aborted ewes The incidence of Ovine brucella by Rose Bengal plate test, Buffered acidified plate antigen test and Rivanol test were $3.75 \%, 3.125 \%$ and $2.5 \%$ respectvely. These strains were biotyped as Brucella melitensis biovar3. Salmonellas spp could be isolated from examined samples with percentage of (9.4\%). Serotypeing of 15 isolates revealed 8 (5.0\%) S. abortus ovis (O4, 12: c: 1, 6), 5 (3.1\%) S.dublin (O1, 9, 12: g, p) and 2 (1.3) S. enteriditis (O1, 9, 12: g, m). Latex test was as a rapid serological test, revealed 12 isolates of 15 isolates were identified as Salmonella species with incidence of (80\%). The overall incidence of Listeria monocytogenes isolated was 5 (3.1\%). including 4 (7.2\%) from abortion cases and $1(0.95 \%)$ from repeat breeder case. Antibiotic sensitivity test for Campylobacter fetus subsp fetus was highly sensitive to Chloramephenical, Gentamycin, Ciprofloxacin and Oxytetracycline with incidence $(90 \%),(80 \%),(70 \%)$ and $(70 \%)$ respectively, while was resistant to Penicillin, Nalidixic acid, Erythromycin, and Ampcillin with incidence $(100 \%),(100 \%),(80 \%)$ and $(70 \%)$ respectively. The hygienic significant of the bacteria isolates were discussed.

Key words: Ewes, abortion, repeat breeder, Campylobacter spp, Brucella spp. Listeria monocytogenes and Salmonella spp.

\section{INTRODUCTION}

Many bacteria present in genital tract as saprophytes but under unfavorable conditions might become pathogenic and causes clinical or sub-clinical signs of endometeritis (AboEl-Ata, 1973). The role of specific aetiological agents such as Brucella spp., Campylobacter spp., Leptospira spp., Listeria monocytogenes, Chlamydia psittaci, Coxiella burnetii, Mycoplasma bovigenitalium and Salmonella spp. has been well 
established, as the main causative of infertility in animals (Radostts et al., 1995). Listeria monocytogenes, Campylobacter fetus subsp. fetus, Yersinia pseudotuberculosis and Toxoplasma gondii are probably representing the most common causes of abortion in sheep Jorgen et al. (2006).

Campylobacter fetus is divided into two subspecies: Campylobacter. fetus subsp. venerealis and Campylobacter fetus subsp. fetus. Campylobacter. fetus subsp. fetus and C. jejuni can cause late term abortions, stillbirths and weak lambs in sheep. Campylobacter is an inhabitant of the intestine of cattle and sheep and then invades the pregnant uterus of cows and ewes causing abortion (Laing, 1960). Campylobacteriosis is a true zoonotic disease occurring naturally in many domestic, laboratory and wild animals. It has been isolated from a variety of causes of abortion in domestic animals including sheep and goats (Anderson et al., 1983). Campylobacter species are now recognized by veterinarians as cause of vibrionic infertility and abortion in cattle and sheep (Matin, 1989).

Brucella infection in farm animals is considered a great problem in most countries of the world, thus the early detection of brucella infection in a herd or flock is a pre-request for the successful control and elimination of one of the major problems considered to be a predisposing factor leading to infertility and sterility along with the possible transmission of infection to man (FAO/WHO, 1986 and Wasseif, 1992). Brucellosis still constitutes one of the major health problems in both man and animals in Egypt. It is the main cause of breeding failure and infertility of affected animals (EL-Gibaly, 1969; Shalaby, 1986 and Soliman, 1998). Ovine and caprine brucellosis still constitutes a serious problem in Egypt due to economic losses and their role in transmission of infection to cattle and buffaloes. Brucellosis in goats and sheep are manifested by abortion which occurs most frequently in the third or fourth month of pregnancy, arthritis and orchitis (Acha and Szyfres, 1991).

The accepted species of Brucella are B. abortus (biovars 1 to 9), B. suis (biovars 1 to 5), B. melitensis (biovars 1 to 3), B. ovis, B. canis and B. neotomae (Feketee et al., 1992).

Brucellosis melitensis biovar3 is the prevalent strain in Egypt among sheep (EL-Gibaly, 1993).

Verma et al. (2000) isolated four Brucella melitensis biotype from 28 aborted ewes with incidence of (14.3\%). 
El-Hewairy et al. (2007) isolated Brucellosis melitensis biovar3 from five goats and two sheep by bacteriological examination, while could detected Brucellosis melitensis biovar3 from nine goats and eight sheep by RBPT and RIV tests

Salmonella abortus ovis causes a contagious infection disease with abortion in ewes accompanied with mortality of lambs (Jack, 1968, Pardon et al., 1988 and Rubino et al., 1993). Salmonella dublin can cause both enteritis and abortion in adult sheep, and the disease is often associated with metritis, anorexia, and loss of wool (Jack, 1971). Salmonella abortus ovis isolated in Egypt association with S.typhinurium and other untyped salmonella strains by of and AbdelGhani (1979).

Listeriosis is called Circling Disease or Silage Sickness, is a disease of worldwide occurrence that can affect all ruminants as well as other animal species and human. It is, therefore, of zoonotic importance. The causative agent is usually Listeria monocytogenes; however ruminants, mainly sheep (Finley and Dennis, 1999). In a survey of an outbreak of listeria abortion in ewes Dennis (1966) indicated that $20(50 \%)$ out of 40 ewes, while, Low and Renton (1985) succeeded in detecting listeria monocytogens in an outbreak of abortion involving 59 out of 196 pregnant ewes. Hassanein (1994) isolated 2 positive cases of listeria monocytogens from 178 cases of sheep with incidence of $(1.1 \%)$.

The present study focused on the pathogenic bacteria associated with cases of infertility in sheep through isolation and identification of these bacteria with special reference to Campylobacter fetus subsp. fetus infection and its sensitivity to some different antimicrobial agents.

\section{MATERIALS and METHODS}

\section{1- Animals:}

A total of 160 ewes out of 600 were used in present study having a history of infertility (55 abortion, and 105 repeat breeders) collected from private farms in El-Mini and Assiut Governorates, illustrated in Table (1).

\section{2- Samples:}

Samples for bacteriological examination including vaginal swabs, faetal fluid, liver and stomach content of aborted faeti, placenta and blood. All samples were transmitted in an ice box to laboratory as soon as possible.

\section{A- Vaginal swabs}


Samples may be obtained by swabbing and or by washing the vaginal cavity. After cleaning the vulval region, the vaginal cavity is washed by infusing 10-20 $\mathrm{ml}$ of sterile phosphate buffered saline (PBS) into the cavity through a syringe attached to a sterile catheter. The fluid is sucked out and reinfused four to five times before being collected in a sterile flask containing enrichment medium.

\section{B- Aborted fetuses and placentas:-}

Specimens of the placenta of aborted ewes, stomach contents, lungs and liver of the fetus were taken under aseptic conditions and sent to the laboratory in a cooled insulated container (at $4-8^{\circ} \mathrm{C}$ ). All samples should be inoculated directly on to broth media and then culture on selective medium.

\section{C- Blood samples:}

About of $10 \mathrm{ml}$ of whole blood was obtained in sterile test tubes. These samples were kept over night at $4{ }^{\circ} \mathrm{C}$ to allow separation of serum, then removed by Pasteur pipette and centrifuged at $3000 \mathrm{rpm}$ for 10 minutes. The clear serum was transferred into test tubes for each samples and labeled unless immediately used and stored at $-20^{\circ} \mathrm{C}$ in deep freezer.

Isolation and identification of Campylobacter fetus subsp. fetus and C. jejuni according to (Bates, 1981):

Dark field and phase contrast preparations of samples from the placenta, fetal abomasum and uterine discharge appeared as an "S" shape with one or two spirals. Each sample is inoculated directly on to a selective medium Campylobacter selective medium (Skirrow, 1977) and Neomycin blood agar medium (neomycin sulphate solution) was added to the media just before the additions of blood to make final concentration of $150 \mathrm{ug} / \mathrm{ml}$. The plates are incubated at $25^{\circ} \mathrm{C}, 37^{\circ} \mathrm{C}$ and $42^{\circ} \mathrm{C}$ for $2-5$ days by using (Gas-pack anaerobic jar "BBL-814-12"). It was used for production of anaerobiosis by using disposable hydrogencarbon dioxide bags with socket. Microaerobic atmospheres of 5-10\% oxygen, 5-10\% carbon dioxide (and preferably 5-9\% hydrogen) were provided (Baker platinum LTD, London). Colonies are slightly greypink, round, convex, smooth and shiny with a regular edge.

The organism was identified by their morphology. Culture smears were made and stained with Gram's and diluted Carbol fuchins. Motility of the organism was examined by the hanging-drop method. Several biochemical tests were applied according to (Konemann et al., 1992 and Levett 1991). Catalase test, oxidase test, nitrate reduction, $\mathrm{H}_{2} \mathrm{~S}$ production test on TSI media and by using lead acetate. Catalase activity was checked by placing a drop of $\mathrm{H}_{2} \mathrm{O}_{2}$ on a slide and a loopful of the 
isolate emulsified in it. The presence of gas bubbles within 10 seconds was considered as catalase- positive.

Growth temperature was checked by incubation of one plate of selective medium and one plate of blood agar at $25^{\circ} \mathrm{C}$ and another plate of each media at $42^{\circ} \mathrm{C}$ for 3 days. The plates were then checked for growth (Campylobacter fetus subsp. fetus does not grow at $42^{\circ} \mathrm{C}$ ).

\section{Isolation and identification of Brucella spp.}

\section{1- Culture:}

Isolation, identification and typing of isolated Brucella strains were done according to the methods recommended by Alton et al. (1988). Samples were direct cultured on the surface of two plates of Brucella selective medium (Difco Laboratories, Detroit, Michigan, USA) at $37^{\circ} \mathrm{C}$ by using (Gas-pack anaerobic jar "BBL-814-12"). It was used for production of an atmosphere of $10 \% \mathrm{CO}_{2}$ tension automatically. All culture plates were examined for brucella growth at $4^{\text {th }}$ day and daily for 10 days till 14 days. Suspected colonies were further identified and sub cultured on brucella agar slopes.

Identification of Brucella isolated was according to morphological characters, microscopically examination and reaction with positive sera. For microscopical examination using a smear on a clean air-dried slide, heat fixed, stained with Modified Ziehl-Neelsen stain and examined for the presence of Brucella-coccobacilli.They were also biochemically characterized as described by Farrell (1974), Buchanon and Gibbons (1974), Morgan, et al. (1978), Alton et al. (1988) and Carter (1995).

\section{2- Serological tests for brucellosis:}

a- Buffered acidified plate antigen test (BAPAT): The test was carried out according to Alton et al. (1988)

b- Rose Bengal plate test (RBPT): The test was carried out according to Morgan et al. (1978)

c - Rivanol test (Riv.T): The test was carried out according to Alton et al. (1988)

\section{Antigens:}

Antigen for standard Buffered acidified plate antigen test (BAPAT), Rose Bengal plate test (RBPT) and Rivanol test (Riv.T) were obtained from Veterinary Vaccines and Sera Research Institute, Abbasya, Cairo, Egypt.

\section{Isolation and identification of Listeria spp.:}

Selective enrichment method.

This method recommended by Curtis et al. (1989). 
Samples of aborted foeti were macerated and thoroughly homogenized under aseptic conditions with sterile distilled water. One $\mathrm{ml}$ of the homogenized specimens was immersed in $9 \mathrm{ml}$ of listeria enrichment broth and incubated at $30^{\circ} \mathrm{C}$ for 48 hours and cultured on to plates of listeria aesculin selective agar. Colonies were picked up and purified by subculturing on same selective media, then kept on nutrient agar sloops for identification on basis of microscopical appearance, culture character, motility, biochemical and serological tests.

\section{Isolation and identification of Salmonella:}

\section{1- Culture}

A loopful from each sample was streaked on to MacConkey's agar plates and S.S agar incubated at $37^{\circ} \mathrm{C}$ for $24-48$ hours. Different colonies were picked up and purified by subculturing on selective media, then kept on nutrient agar sloops for identification of microscopical appearance, culture character, motility, biochemical identification according to (Edward and Ewing, 1972, Buchanan and Gibons, 1974 Cruickshnk et al., 1982, Speck, 1984 and Wilson and Miles, 1985).

\section{2- Latex test:}

The suspected colonies were subjected to latex test according to Mitrutina and Tendetnik (1994) as rapid test for diagnosis and confirm that the isolated colonies were salmonellae

\section{3- Serological identification of Salmonella}

Typing of Salmonella isolates was applied to identify the serovars of the isolated colonies using polyvalent and monvalent antisera. "O" and " $\mathrm{H}$ " antigens as well as the phase of the organism were detected by using Agglutination sera test according to the modified Kauffmanns and White scheme described by (Mcwhorter et al., 1977, Baily and Scott 1990, Brenner 1994 and Quinn et al., 1994). Suspected culture was mixed thoroughly with a drop of saline on clean slide. A small drop of polyvalent Salmonella antisera was mixed thoroughly with the bacteria suspension by tilting the slide for one minute. Positive agglutination was recognized by formation of fine granules or large aggregate, delayed or partial agglutination was considered as negative or false agglutination. Cultures which gave positive results were similarly tested using monovalent group for determination of specific "O" antigen and within group of " $\mathrm{H}$ " antigen both phase, 1 and phase 11 . The sera used were purchased from Wellcome Research Laboratories Beckengham, England. The serological tests were carried out in Ministry of health laboratories in Cairo as well as Serology Unit, Animal Health Institute, Giza, Egypt 


\section{Sensitivity test for Campylobacter fetus subsp. fetus}

Determination of the antibiogram of Campylobacter fetus subsp. fetus to antimicrobial agent, it was carried according to (Lannette et al., 1985 and Perelman et al., 1991). Ten different antibiotic discs, supplied by Oxoid LTD, London, England, (Oxoid Manual, 1982). These antibiotics were Penicillin (1.5 I.U) Nalidixic acid, Streptomycin (10ug) Ciprofloxacin (5ug), Chloramephenical (30ug), Oxytetracycline (30ug), Erythromycin, Gentamicin, Amoxicillin (10ug) and Ampicillin. One ml of $24 \mathrm{hr}$. broth cultures was spread on the surface of blood agar. Antibiotic sensitivity discs were placed on the surface seeded agar. Plates were incubated anaerobically at $37^{\circ} \mathrm{C}$ for $24 \mathrm{hr}$. The sensitivity was judged according to the diameter of clearance zone around the discs

\section{RESULTS}

Table 1: Number and percentage of examined ewes.

\begin{tabular}{|c|l|c|c|}
\hline \multirow{2}{*}{$\begin{array}{c}\text { Total No. of studied } \\
\text { ewes }\end{array}$} & Healthy status & \multicolumn{2}{|c|}{ No. of infected cases } \\
\cline { 3 - 4 } & & No. & $\%$ \\
\hline \multirow{2}{*}{600} & Abortion & 55 & 9.2 \\
\cline { 2 - 4 } & Repeat breeder & 105 & 17.5 \\
\cline { 2 - 4 } & Total & 160 & 26.7 \\
\hline
\end{tabular}

Table 2: Biochemical characteristics of isolated Campylobacter strains.

\begin{tabular}{|l|c|c|}
\hline Characteristics & C. fetus subsp fetus & C. jejuni \\
\hline Catalase reaction & + & + \\
\hline Oxidase & + & + \\
\hline Motility & + & + \\
\hline H2S production & \multicolumn{2}{|c|}{} \\
TSI & - & + \\
\cline { 2 - 3 } Lead acetate & + & - \\
\hline Growth & \multicolumn{2}{|}{} \\
\cline { 2 - 3 } at $25{ }^{\circ} \mathrm{C}$ & + & + \\
at $37^{\circ} \mathrm{C}$ & + & + \\
at $42^{\circ} \mathrm{C}$ & - & - \\
\hline Growth in: & \multicolumn{2}{|}{} \\
\cline { 2 - 3 } $3.5 \% \mathrm{NaCL}$ & - & + \\
\cline { 2 - 3 } $1 \%$ glycine & + & \\
\cline { 2 - 3 } & & \\
\cline { 2 - 3 }
\end{tabular}

Table 3: Type and percentage of different bacterial isolates from 160 ewes (55 abortions and 105 repeat breeders).

\begin{tabular}{l|l|l} 
Isolates & Positive & Healthy status \\
\hline
\end{tabular}




\begin{tabular}{|c|c|c|c|c|c|c|}
\hline \multirow{2}{*}{} & \multicolumn{2}{|c|}{ isolates } & \multicolumn{2}{c|}{$\begin{array}{c}\text { Abortion } \\
(55)\end{array}$} & \multicolumn{2}{c|}{$\begin{array}{c}\text { Repeat breeder } \\
(105)\end{array}$} \\
\cline { 2 - 7 } & No. & $\%$ & No. & $\%$ & No. & $\%$ \\
\hline Campylobacter spp. & 16 & 10 & 12 & 21.8 & 4 & 3.8 \\
\hline C. fetus subsp fetus & 12 & 7.5 & 10 & 18.2 & 2 & 1.9 \\
\hline C. jejuni & 4 & 2.5 & 2 & 3.6 & 2 & 1.9 \\
\hline Brucella melitensis biovar3 & 6 & 3.75 & 6 & 10.9 & 0 & 0.0 \\
\hline listeria monocytogens & 5 & 3.1 & 4 & 7.2 & 1 & 0.95 \\
\hline Salmonella spp. & 15 & 9.4 & 11 & 20.0 & 4 & 3.8 \\
\hline S. abortus ovis & 8 & 5.0 & 6 & 14.5 & 2 & 1.9 \\
\hline S.dublin & 5 & 3.1 & 3 & 5.4 & 2 & 1.9 \\
\hline S. enteriditis & 2 & 1.3 & 2 & 0.0 & 0 & 0.0 \\
\hline Total & 42 & 26.3 & 33 & 54.5 & 9 & 8.6 \\
\hline
\end{tabular}

Percentage of positive isolates calculated according to the total number of samples Percentage of each isolates was calculated according to the type of healthy status

Table 4: Serological tests used for detection of Brucella melitensis biovar3.

\begin{tabular}{|c|c|c|c|c|c|c|c|c|c|}
\hline \multirow{2}{*}{$\begin{array}{c}\text { No of } \\
\text { examined } \\
\text { samples }\end{array}$} & \multicolumn{10}{|c|}{ Serological tests } \\
\cline { 2 - 10 } & \multicolumn{2}{|c|}{ RBPT } & \multicolumn{2}{|c|}{ BAPAT } & \multicolumn{6}{c|}{ Rivanol test } \\
\hline \multirow{2}{*}{160} & $+\mathrm{ve}$ & $\%$ & $+\mathrm{ve}$ & $\%$ & $1 / 25$ & $1 / 50$ & $1 / 100$ & $1 / 200$ & $1 / 400$ \\
\cline { 2 - 10 } & 6 & 3.75 & 5 & 3.125 & - & 1 & 1 & 1 & 1 \\
\hline
\end{tabular}

RBPT $=$ Rose Bengal plate test

BAPAT $=$ Buffered acidified plate antigen test

Table 5: Result of Latex test for Salmonella.

\begin{tabular}{|c|c|c|c|c|c|}
\hline \multirow{2}{*}{ No. of samples } & \multirow{3}{*}{ No. of isolates } & \multicolumn{4}{|c|}{ Latex test } \\
\cline { 3 - 6 } & & \multicolumn{3}{|c|}{ Positive } & \multicolumn{2}{c|}{ Negative } \\
\cline { 3 - 6 } & 15 & No. & $\%$ & No. & $\%$ \\
\hline 160 & 12 & 80 & 3 & 20 \\
\hline
\end{tabular}

Percentage of positive case was calculated according to the number of Salmonella isolates

Table 6: Serotyping of Salmonella isolates.

\begin{tabular}{|l|c|c|c|c|c|c|c|c|c|}
\hline \multirow{2}{*}{$\begin{array}{c}\text { Source of } \\
\text { samples }\end{array}$} & \multirow{2}{*}{$\begin{array}{c}\text { No. } \\
\text { of } \\
\text { cases }\end{array}$} & \multicolumn{2}{c|}{$\begin{array}{c}\text { No. of } \\
\text { isolates }\end{array}$} & \multicolumn{2}{c|}{$\begin{array}{c}\text { S.abortus } \\
\text { ovis }\end{array}$} & \multicolumn{2}{|c|}{ S.dublin } & \multicolumn{2}{|c|}{ S. enteriditis } \\
\cline { 3 - 11 } & No. & $\%$ & No. & $\%$ & No. & $\%$ & No. & $\%$ \\
\hline Abortion & 55 & 11 & 20 & 8 & 14.5 & 3 & 5.4 & 0 & 0.0 \\
\hline Repeat breeder & 105 & 4 & 3.8 & 0 & 0.0 & 2 & 1.9 & 2 & 1.9 \\
\hline Total & 160 & 15 & 9.4 & 8 & 5.0 & 5 & 3.1 & 2 & 1.2 \\
\hline
\end{tabular}

Percentage of each strain was calculated according to the number of each case

Table 7: Antibiotic sensitivity test for Campylobacter fetus subsp. fetus isolated. 
Assiut Vet. Med. J. Vol. 54 No. 119 October 2008

\begin{tabular}{|c|c|c|c|c|c|c|}
\hline \multirow[t]{3}{*}{ Antibacterial agent } & \multicolumn{6}{|c|}{ Campylobacter fetus subsp fetus. $(\mathrm{n}=10)$} \\
\hline & \multicolumn{2}{|c|}{$\mathrm{S}$} & \multicolumn{2}{|c|}{ I } & \multicolumn{2}{|c|}{$\mathrm{R}$} \\
\hline & No. & $\%$ & No. & $\%$ & No. & $\%$ \\
\hline Penicillin (1.5 I.U) & 0 & 0.0 & 0 & 0.0 & 10 & 100 \\
\hline Ampcillin(10ug) & 2 & 20 & 1 & 10 & 7 & 70.0 \\
\hline Streptomycin(10ug) & 4 & 40 & 5 & 50 & 1 & 10 \\
\hline Erythromycin (15ug) & 0 & 0.0 & 2 & 20.0 & 8 & 80.0 \\
\hline Amoxicillin(10ug) & 3 & 30 & 2 & 20 & 5 & 50 \\
\hline Ciprofloxacin (10ug). & 7 & 70 & 2 & 20 & 1 & 10 \\
\hline Chloramephenical (30ug) & 9 & 90 & 1 & 10 & 0 & 0.0 \\
\hline Oxytetracycline(30ug) & 7 & 70 & 2 & 20 & 1 & 10 \\
\hline Gentamycin (10ug) & 8 & 80 & 0 & 0.0 & 2 & 20 \\
\hline Nalidixic acid (30ug) & 0 & 0.0 & 0 & 0.0 & 10 & 100 \\
\hline
\end{tabular}

$+++=$ Highly sensitivity, ++ = Intermediate sensitivity $R=-$ Resistance

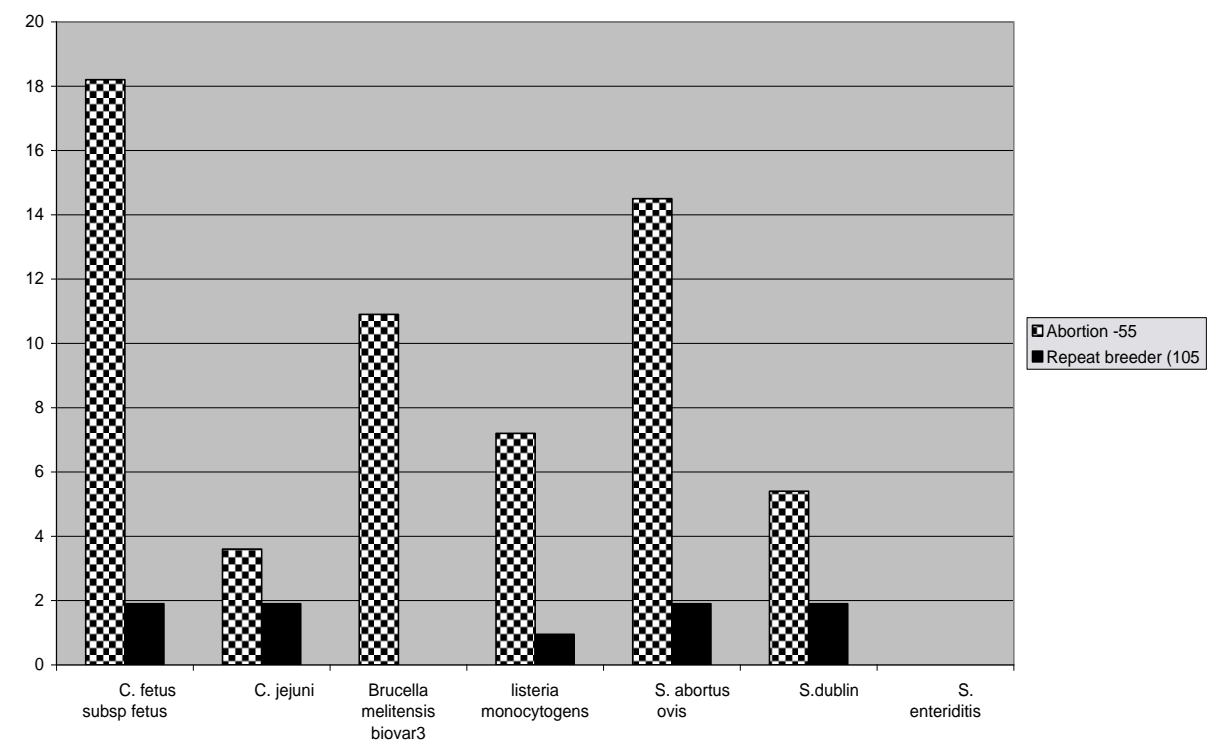

Fig. 1: Percentage of bacterial isolate from abortion and repeat breeder cases

\section{DISCUSSION}

Bacterial pathogens were the most prevalent cause of abortion. Several of the abortifacients were zoonotic microorganisms, for example Listeria monocytogenes, Campylobacter fetus subsp. fetus, Yersinia pseudotuberculosis and Toxoplasma gondii. The identified 
microorganisms probably represent the most common causes of abortion in Danish sheep (Agerholm et al., 2006).

The present work, as an investigation trial focused on bacteria causing infertility in sheep. 160 ewes out of 600 were show clinical sings. Out of these, 55 suffered from abortions with a percentage of $(9.2 \%)$ and 105 suffered from repeat breeding with a percentage of $(17.5 \%)$ as in table (1)

\section{Campylobacter fetus subsp. fetus and Campylobacter jejuni}

There are several species within the Campylobacter genus (C.fetus and C.jejuni) that are considered pathogenic to both human and animals (Vargas et al., 2003). C. fetus is divided into subspecies and may be found in the genital tract causing infertility or sporadic abortion (Maclaren and Agumbah, 1988). Infection with Campylobacter fetus subsp. fetus and Campylobacter jejuni results in abortions in late pregnancy or stillbirths. Identification of the species involved is important because in some areas, $C$ jejuni is as common as $C$ fetus, all the isolates encountered in this investigation detected using of culture on selective media, biochemical reaction and serological tests. From direct smears, it appears as an "S" with one, two or several spirals. The isolates were positive to catalase reaction, oxidase, motility, growth at $25^{\circ} \mathrm{C}$ and $37^{\circ} \mathrm{C}$ but not growth on $42^{\circ} \mathrm{C}$, production of $\mathrm{H}_{2} \mathrm{~S}$ on lead acetate but not on TSI (Table, 2). These results agreed with Eaglesome and Garcia (1992), Taylor (1992), Elham (2000), Vargas et al. (2003) and Mona and Hassan (2004). A total of $16(10 \%)$ isolates identified as being campylobacter were recovered, of which 12 isolates from abortion cases with incidence of $(21.8 \%)$ and 4 isolate from repeat breeder with incidence of $(3.8 \%)$. Moreover 12 isolates out of the 16 isolates were identified as C. fetus subsp fetus with incidence of (7.5\%) and 4 isolates as $C$. jejuni with incidence of (2.5\%) Table (3). These results are nearly in agreement with those recorded by Elham (2000) but differed in the incidence of the species, where isolated Compylobacter. fetus and Compylobacter jejuni were $3.3 \%$ and $8.3 \%$ respectively. Mona and Hassan (2004) recovered 13 isolates of campylobacter species from aborted foeti and vaginal mucous of farm animals included 6 bovine origin, 2 of ovine origin, 2 from caprine origin and 3 from camels in agreement with results of the present study.

\section{Brucellosis}

Control of brucellosis depend on the use of efficient serodiagnostic tests. However, no single test is capabale of identifying all positive cases (Morgan et al., 1978). Ovine and caprine brucellosis still 
constitutes a serious problem in Egypt due to economic losses and their role in transmission of infection to cattle and buffaloes. Brucellosis in goats and sheep are manifested by abortion which occurs most frequently in the third or fourth month of pregnancy, arthritis and orchitis (Acha and Szyfres, 1991). Isolates of brucellae encountered were small, non-motile, non-sporing, Gram-negative bacilli or coccobacilli appear single, but may be in pairs or small groups as described by Buchanon and Gibbons (1974) and Carter (1995). In the present study, the incidence of brucellae isolates was $6(3.75 \%)$ from only aborted ewes (Table, 3). This results are agreement with Moorthy and Singh (1982) who isolated brucellae from ewes with incidence of (3.2\%), while higher than that recorded by Verma et al. (2000) who isolated brucellae from ewes with incidence of $(2.45 \%)$. Bassiony and Ibrahim (1997), Samaha et al. (2002), Ding (1993) and Revviriego et al. (2000) reported similar results but lower than that reported by Mosalam (1993) who isolated Brucella melitensis biovar3 with incidence of (22.22\%) from aborted foeti of sheep. Dawood (1977) isolated Brucella melitensis biovar3 from sheep and goats with incidence of $(20.63 \%)$ and (19.23\%) respectively. The serological tests of ovine Brucella by Rose Bengal plate test, Buffered acidified plate antigen test and Rivanol test were $3.75 \%, 3.125 \%$ and $2.5 \%$ respectively (Table, 4 ). The difference in the incidence of infection detected by three serological tests is probably due to the difference in the sensitivity of these tests and /or the vaccination status of tested animals. These strains were biotyped as Brucella melitensis biovar3. These results are higher than obtained by Montasser (1999) who isolated Brucellosis melitensis biovar3 from sheep by using serological tests, CFT, SAT, BAPAT, RBPT and Rivonol test with incidence of $1.18 \%, 1.3 \%, 1.61 \%, 099 \%$ and $0.95 \%$, respectively, while lower than that reported by Shalaby et al. (2003) who isolated Brucella melitensis type 3 from sheep with incidence $9.8 \%$ by using Rose Bengal Plate Test (RBPT) as a rapid screening quantitative test and $8.06 \%$ by using Rivanol test (Riv.T). In accordance, El-Hewairy et al. (2007) detected Brucellosis melitensis biovar3 from sheep by using RBPT, STAT and RIV test with incidence of $5.3 \%, 3,3 \%$ and $5.3 \%$, respectively.

\section{Salmonellas spp}

Isolates of Salmonella were non-lactose fermented with $\mathrm{H}_{2} \mathrm{~S}$ on MacConkey agar and S.S agar, haemolytic on blood agar, gram negative and short rods. The isolates were urease and oxidase negative, released $\mathrm{H}_{2} \mathrm{~S}$ on triple sugar iron (TSI). These results were in agreement with 
Engler (1988), Brenner (1994) and Turutoglu et al. (2000). Data presented in Table (3) revealed that Salmonellas spp could be isolated from examined samples with percentage of $15(9.4 \%)$. Latex test was as a rapid serological test; revealed 12 isolates of 15 isolates were identified as salmonella species with incidence of $80 \%$ (Table, 5). These results are in agreement with Pardon et al. (1988) and Bourgogne, (1998) and lower than that obtained by Soumaya et al. (2004) who isolated 252 serotypes of Salmonella from 377 different samples obtained from aborted ewes, fetuses with incidence of $66.8 \%$ belonged to S. abortus ovis (92\%), S.dublin (4\%) and S. enteriditis (0.8\%). Latex test is a rapid serological test, where $92.8 \%$ of 252 isolates were identified as Salmonella species, Sereotyping of 15 isolates revealed $8(5.0 \%)$ S. abortus ovis (O4, 12: c: 1, 6), $5(3.1 \%)$ S.dublin $(\mathrm{O} 1,9,12: \mathrm{g}, \mathrm{p})$ and 2 (1.3) S. enteriditis (O1, 9, 12: $\mathrm{g}, \mathrm{m})$ as in Table (6).

\section{Listeria monocytogenes}

Microscopical examination of samples Listeria appears as small, Gram-positive rods, nonperforming, catalase-positive, which are sometimes arranged in short chains. In direct smears they were coccoid, Flagella are produced at room temperature but not at $37^{\circ} \mathrm{C}$. Hemolytic activity on blood agar has been used as a marker to distinguish Listeria monocytogenes among other Listeria species. This is in agreement with George (2002). Infection by L. monocytogenes has been reported to be increasing in incidence and may be as high as $52 \%$ in farm animals (Rebhun, 1995). The present study recorded that the overall incidenc of Listeria monocytogenes was 5 (3.1\%) including 4 (7.2\%) from abortion cases and $1(0.95 \%)$ from repeat breeder cases (Table, 3). These results higher than that obtained by Fedio and Jackson (1992) who estimated an attack rate of $0.4 \%$, Lida et al. (1991) and Hassanein, (1994) reported similar results while lower than obtained by Dennis (1966) and Low and Renton (1985).

\section{Antimicrobial sensitivity test: -}

The extensive use of antibiotics as growth promoters and prophylactic agents for disease control in veterinary medicine has undoubtedly been responsible for large numbers of bacteria that have become resistant to different antibiotics. Results of the antibiotic susceptibility pattern of Campylobacte fetus subsp fetus are clearly shown in Table (7). Campylobacter fetus subsp fetus were highly sensitive to, Chloramephenical (90\%), Gentamycin (80\%), Ciprofloxacin $(70 \%)$ and Oxytetracycline $(70 \%)$. while was resistant to Penicillin (100\%), Nalidixic acid (100\%), Erythromycin (80\%), and 
Ampcillin (70\%). These results are in agreement with those of many authors. Vicek and Savobodova (1985) reported that the bacterial isolates from cases of repeat breeder were susceptible to Oxytetracycline and Chloramphenica. Also Ramakrishna (1996) found that, bacterial isolates from repeat breeder cows were sensitive to Gentamycin (89.1\%). Elham (2000) found that Campylobacter fetus subsp fetus isolated from aborted fetus and cervical swabs of ewes was sensitive to Gentamycin and sulfamethoxazol while resistance to Ampicillin, Nalidixic acid, and Erythromycin. Metwelly (2001) recorded that, the invitro antimicrobial susceptibly of bacterial isolates from cows with endometeritis were Enrofluxacin, Oxytetracycline, Gentamycin and Ampicillin with incidence of 96.0, 89.0, 85.0 and 85.0\%, respectively. Karwani and Aulakh (2004) reported that, out of total 155 isolates from repeat breeder cattle and buffaloes maximum isolates $146(94 \%)$ were found sensitive to Ciprofloxacin followed by Gentamicin 115 (74\%) and Chloramphenicol (67\%). Also these results are in agreement with that obtained by Hassab El-Naby and El-Ekhnay (2004) who mentioned that bacteria causing repeat breeding in cattle and buffaloes, were more sensitive to Enerofloxacin, Gentamicin and Chloramphenicol. These results are nearly similar to those obtained by Awad et al. (1977) and Megahed (1986) who recorded that the bacterial isolates were resistant to Erythromycin and Penicillin. Refaat (1980) reported that the bacterial isolates from buffaloe-cows suffering from repeat breedingr were moderately sensitive to Erythromycin and Karwani and Aulakh (2004) who found that isolates from repeat breeder cattle and buffaloes showed resistance to Penicillin, Ampicillin, Neomycin and Naledixic acid with varying degree of drug resistance.

\section{REFERENCES}

Abo-El-Ata, M.M. (1973): Studies on chronic endometeritis in Egypt. M.D. Vet. (Gynecology) Thesis, Cairo Univ.

Acha, P.N. and Szyfres, B. (1991): Zoonoses and communicable diseases common to man and animals $2^{\text {nd }}$ Ed Pan American Health Organization, Washington D.C., USA.

Agerholm, J.S.; Aalbak, B.; Fog-Larsen, A.M.; Boye, M.; Holm, E.; Jensen, T.K.; Lindhardt, T.; Larsen, L.E. and Buxton, D. (2006): Veterinary and medical aspects of abortion in Danish sheep. APMIS; 114: 146-52. 
Alton, G.G.; Jones, L.M.; Angus, R.D. and Veger, J.M. (1988): Techniques for the Brucellosis Laboratory. INRA, Publication Paris, ISEN, France.

Anderson, K.L.; Hamoud, M.; Urbance, J.W.; Rhoades, H.E. and Bryner, J.H. (1983): Isolation of Campylobacter jejuni from an aborted caprine fetus. J. Amer. Vet. Med. Associ., 183: 90-92.

Awad, H.H.; Afiefy, M.M. and Ayoub, M.M. (1977): Genital discharges in an infertile herd, their causes and treatment. Assiut Vet. Med. J. 4 : 219-229.

Bailey, W.R. and Scott, S.G. (1990): Diagnostic microbiology, $7^{\text {th }}$ Ed. C.V.Mosby Co., U.S.A.

Bassiony, M.M. and Ibrahim, I.G. (1997): Bacteriological and immunological profiles of brucellosis in sheep and goats. Assi. Vet. Med. J., 36 (72): 255-261.

Bates, P.G.J. (1981): Isolation and identification of Campylobacter, Medium 14, 8-17.

Bourgogne, A.; Sanchis, R.; Clement, J.M. and Pepin, M. (1998): Salmonelosis abortus, strains Rv6 a new vaccinal vehicles for small ruminants Vet. Microbiology, 61, (3): 199-203.

Brenner, D.J. (1994): Family Enterobacteriaceae sp. 408-516.In Krieg and J.G.Holt (Ed). Bergey's Manual of systemic bacteriology, Vol. 1 Wilkins, Baltimore.

Buchanon, R.S. and Gibbons, N.E. (1974): Bergey's Manual of Determinative Bacteriology. $8^{\text {th }}$ Ed. The Williams Wilkins Company. Baltimore.

Carter, G.R. and Cole, J.R. (1995): Diagnostic Procedures in Veterinary Bacteriology and Mycology. 6th ed. Academic Press Inc. California, USA.

Cruickshank, R.; Duguid, J.P.; Marmoni, B.P. and Swain, R.H. (1982): Medical Microbiology. $12^{\text {th }}$ Ed., Churonill Livingestone Edingurg, London, UK.

Curtis, G.D.; Mitchell, M.G.; King, A.F. and Griffin, E.J. (1989): Differentiation medium for the isolation of Listeria monocytogenes, Applied Microbiology 8, 95-98

Dawood, F.A. (1977): Some studies on brucellosis in sheep and goats in Dumyat Governorate. Thesis for the degree of ph.D. (Infectious disease), Faculty of Veterinary Medicine, Zagazig University, Egypt. 
Dennis, M. (1966): Perinatal lamb mortalities in Western Australia, FR CVS. Thesis, Royal collage of Veterinary Surgeons, London, UK.

Ding, X.L. (1993): Investigations on the epidemiology of brucellosis in some villages (Pasturelands) of Su. Country, Gansu Province. Chung Hua Liu Hsing Ping Husuch Tsa China, 11 (6) 338-340.

Eaglesome, M.D. and Garcia, M.M. (1992): Microbial agents associated with bovine genital tract infection and semen. Part 1. Brucella abortus, Leptospira, Campylobacter fetus and Trichomonas fetus. Vet. Bull.; 62: 743-775.

Edwards, P.R. and Ewing, W.H. (1972): Identification of enterobacteriacae, Burgess Publ. Co.Minnecopolis Minnesota. P.103-104.

EL-Gibaly, M. and Samira, S.M. (1993): Correlation between serotests and isolation of brucella melitensis I an infected sheep farm. Proc. $2^{\text {nd }}$ Sci.Cong. Socity for cattle Disease, Assiut, PP: 194-203.

EL-Gibaly, S.M. (1969): Studies on brucellosis in dairy animals in UAR. M.D. Thesis (Vet. Hygiene) Fact. of Vet. Med., Cairo Unv, Egypt.

El-Hewairy, H.M.; Syame, S.E. and Selim, S.A. (2007): Serological and molecular diagnosis of Brucellosis in sheep and goats in Aswan Governorate. J. Egypt. Vet. Med.Assoc.87, 3: 251-259.

Elham, A.K. Al-Jawally (2000): The causative agents of aborted ewes in Mousl. Iraqi J. Educ. Sci. 36: 237-240.

Engler, K. (1988): Salmonelosis in laboratory animals. Animal Welfare Information Center.

FAO/WHO, (1986): Joint FAO/WHO expert committee on brucellosis $6^{\text {th }}$ report, World Health Organization Tech Rep.No.740 WHO Geneva, Switzerland.

Farrell, I.D. (1974): The development of a new selective medium for the isolation of Brucella abortus from contaminated sources. Res.Vet. Sci, 16, 280-286.

Fedio, W.M. and Jackson, M. (1992): On the origin of Listeria moncytogenes in raw bulk-tank milk. International Dairy Journal 2, 3, 197-208.

Fekete, A.; Bantle, J.A. and Halling, S.M. (1992): Detection of Brucella by polymerase chain reaction in bovine fetal and maternal tissues. Journal of Veterinary Diagnostic investigation, 4, 79. 
Finley, M.R. and Dennis, S.R. (1999): Listeriosis (Circling Disease, Silage Sickness). In Howard \& Smith Current Veterinary Therapy 4: Food Animal Practice. Saunders. Philadelphia, PA, USA, 396-400.

George, L.W. (2002): Listeriosis in Smith, Bradford P. large Animal Internal Medicine. $3^{\text {rd }}$ edition, Mosby, Philadelphia, USA ; 946-949

Hassab EL-Naby, G.R. and EL-Ekhnawy, Kh.I. (2004): Bacterial agents associated repeat breeder cows with special reference to some serum biochemical changes in Gharbia Provience. Alex. Vet. J., Vol. 22, No.1:

Hassanein, A.R. (1994): Epidemiological studies on the occurrence of listeria infection in animals and man. M.V.Sc. Thesis (Zoonoses disease) Fac. Vet. Med. Assiut Univ., Egypt.

Jack, E.J. (1968): Salmonella abortion ovis atypical Salmonella. Vet. Res.82: 558-561.

Jack, E.J. (1971): Salmonella abortion in sheep. Vet. Annul. 12:57-63.

Jørgen, S.; Agerholm, Bent Aalbaek; Anne Marie Fog-Larsen; Mette Boye; Elisabeth Holm, Tim K. Jensen; Ttna Tlndhardt; Lars E. Larsen and David Buxton (2006): Veterinary and medical aspects of abortion in Danish sheep. APMIS 114 (2), 146-152.

Karwani, A. and Aulakh, R.S. (2004): Drug resistance and sensitivity of bacteria from repeat breeding and abortions in bovines 23rd World Buiatrics Congress, Quebec City, Canada, July 11-16.

Koneman, E.W.; Allen, S.D.; Janda, W.; Dowell, V.R. and Winn, W.C. (1992): Color Atlas and Textbook of Diagnostic Microbiology 3rd Ed. J.B. Lippincott Company, Philadelphia, USA.

Laing, J.A. (1960): Vibrio fetus infection in cattle, FAO Agrie. Studies No. 51.

Lannette, E.H.; Balows, A.; Hausler, JRJW. and Shadomy, H.J. (1985):

Manual of clinical microbiology. $4^{\text {th }}$ ed. Washington: American Society for Microbiology, 302-308.

Levett, P.N. (1991): Anaerobic microbiology (A practical approach). Oxford University Press, NewYork.

Lida, T.; Kanzaki, M.; Maruyama, T.; Inoue, S. and Kaneuchi, C. (1991): Prevalence of Listeria moncytogemes in intestinal contents of Healthy Animals I Japan. J. Vet. Med. Sci.53, 5, 873-875. 
Low, J.C. and Renton, C.P. (1985): Septicemia, encephalitis and abortion in a housed flock of sheep caused by Listeria moncytogemes type $1 / 2$ Vet. Res., 116, 147-150.

Maclaren, A.P.C. and Agumbah, G.J.O. (1988): Infertility in cattle in South-west Scotland caused by an intermediate strain of C.f.ss.fetus. Br. Vet.J. 144: 29-44.

Matin, A.E.; Auger, A.; Blum, P.H. and Schultz, J.E. (1989): Genetic basis of starvation survival in non differentiating bacteria. Annul. Rev. Microbiol. 43: 293-319.

McWhorter, A.C.; Fife-Asbury, M.A.; Huntley-Cater, G.P. and Brenner, D.J. (1977): Modified Kauffmamm-white Schema for Salmonella and Arizona. New publication (CDC) No. 63: 77-83. U.S Dept. of HEW, Center for diseases controls Atlanta, Georgia, USA.

Megahed, G.A. (1986): Bacteriological examination of uterine discharges in farm animals during post-partum period. Thesis M.V.Sc. (Theriogenology). Fac. Vet. Med. Assiut. Univ

Metwelly, K.K. (2001): Clinical success and subsequent fertility after intrauterine antibiotics administration in cows with postpartum endometeritis. The $2^{\text {nd }}$ international scientific conference, Monsora, Egypt, 8-9 April pp.1045-1061

Mitrutina, L.N. and Tendetnik, IU.IA. (1994): The use of Latex agglutination test for rapid diagnosis of salmonellosis in children.

Mona, M. Sobhy and Hassan, H.M. (2004): Characterization of Campylobacter species using SDS-PAGE. J. Egyptian Vet. Med. Association Vol. 64 No.4: 281-292.

Montaser, A.M. and Mervat A. Melad (1999): Epizootological studies on brucellosis in cattle, buffaloes, sheep and goats in Fayoum Governorate3rd Sci. Cong. Of Manf. and Beni Suif.

Moorthy, A.R.S. and Singh, S.P. (1982): Studies on the bacterial flora of the female genital tract of sheep. Bull. Anim. Health Production in Africa 30, 15-18.

Morgan, W.J.; Mackkinnon, D.J.; Gill, K.P.; Gowee, S.G. and Norris, P.I. (1978): Standard laboratory techniques for the diagnosis of brucellosis. Report Series No.1, Weybrige Cent. Vet. Lab, England.

Mosalam, E.E.M. (1993): Further studies on brucellosis in sheep and goats. Thesis for degree of ph.D. (Microbiology) Cairo University, Beni-Suef. 
Oof, F. and Abdel-Ghani, M. (1979): Salmonellosis as a bacterial cause of abortion in Egyptian ewes. J. Egypt. Vet. Med. Associate, 39, (1) 105-112.

Oxoid Manual (1982): The Oxoid manual of culture media, ingredients and other laboratory services $5^{\text {th }}$ Ed. Oxoid Limit

Pardon, P.; Sanchis, R.; Marly, J.; Lantier, F.; Pepin, M. and Popff, M. (1988): Ovine salmonellosis caused by Salmonella abortus ovis. Annul. Res.Vet.., 19, (4): 221-235.

Perelman, B.; Mitnts, S.; Zjut, M.; Kuttin, E. and Machny, S. (1991): An unusual Clostridium colinum infection in broiler chickens. Avian Pathology, 20: 475-480.

Quinn, P.J.; Carter, M.E.; Makey, B. and Carter, G.R. (1994): Clinical Veterinary Microbiology Wolf Publishing an impint of Mosbyyear book Europe Limited, Lynton House, 7-10 Tavistock Spuare, London.WC IH9LB, England.

Radosttts, O.M.; Blood, D.C. and Gay, G.C. (1995): Veterinary Medicine, 8th ed. ELBS.

Ramakrishna, K.V. (1996): Microbial and biochemical profile in repeat breeder cows. Indian. J. Anim. Reprod.17 (1): 30-32.

Rebhun, William C. (1995): Listeriosis in Diseases of Dairy Cattle. Lippincott Williams \& Wilkins. Philadelphia, PA 121: 410413.

Refaat, M.A. (1980): Bacteriological causes of repeat breeder in buffalocows. M.V.Sc. Thesis Vet. Med. Assiut Univ.

Revviriego, F.J.; Moreno, M.A. and Domingue, Z.L. (2000): Risk factors for brucellosis seroprevalence of sheep and goats flocks in Spain. Prev. Vet. Med 28: 44(3-4): 167-173.

Rubino, S.; Rizzu, P.; Erre, G.; Colombo, M.M.; Lerio, G.; Gulig, P.A,; Doyle, T.J.; Psano, M.; Uzzaau, S. and Cappuccinelli, P. (1993): Mechanism of pathogenicity in Salmonella abortus ovis Cabello et al (cd), Biology of Salmonella. Plenum Press, NewYork P, 141-147.

Samaha, H.A.; Draz, A.A.; Haggg, Y.N. and Enass, M.A. (2002): Small ruminant as reservoir of certain bacterial and mycotic pathogens to man. Assiut Vet. Med. J. Vol.46 No.92.

Shalaby, M.N.H,; Ghobashy, H.M.; EL-Bauomy, E.M. and Saleh, Wafaa, M.A. (2003): Pervalence of brucellosis among farm animal species in some Governorates in Egypt. $7^{\text {th }}$ Sci, Egyptian Society for Cattle Diseases 7-9 Dec. 2003 Assiut Egypt. 
Shalaby, M.N.H. (1986): A survey on brucellosis as a cause of reproductive disorders in farm animals I Egypt. Ph.D. thesis (Obstetric, Gynecology and AI), Fac. Of Vet. Med. Cairo Unv.

Skirrow, R.M. (1977): Campylobacter enteritis: a "new" disease. Br. Med. J. (2) ; 9-11.

Soliman, S.A. (1998): Studies on brucellosis in farm animals with reference to public health importance in Suez Canal district Ph.D.thesis, Fac. of Med. Suez Canal Univ.

Soumaya, S.A.; EL-Shafh and Fadel, N.G. (2004): Bacteriological study on salmonella abortion in savaolak sheep with special reference to pathological, alterations in different organs of aborted faetal and dead newly born lambs J. Egypt. Vet. Med. Assoc. 64, 4,

Speck, M.L. (1984): Compendium of Methods for the Microbiology Examination of Foods $2^{\text {nd }}$ Ed American Public Health Association, Washington D.C.

Taylor, D.E. (1992): Genetic of Campylobacter and Helicobacter. Annul. Rev. Microbiol, 46: 35-64.

Turutoglu, H.; Iyisan, A.; Ozturk, M. and Gulyaz, V. (2000): Abortions related to Chlamydia psittaci and Salmonella abortus ovis in sheep farm. Pendik Veterinary Mikrobiyoloji Dergisi, 31, (2): 5-17.

Vargas, A.C.; Costa, M.M.; Vaintstein, M.R.; Kreutz, L.C. and Neves, J.P. (2003): Phenotypic and molecular characterization of bovine Campylobacter fetus strains isolated in Brazil. Vet. Microbiol 93: 121- 132.

Verma, S.; Katoch, R.C.; Sharma, M. and NigamI, P. (2000): Abortions and infertility in Livestock due to brucellosis in Himachal Pradesh, India. Vet. Archive 70, 75-82.

Vicek, Z. and Savobodova, R. (1985): Occurrence and antibiotics sensitivity of bacteria present in the cervical mucus of cows in late puerperium and post puerperal period. Acta Vet. Bron, 54, 91-97.

Wasseif, S.M. (1992): Brucellosis in Sharkia Governorate an epidemiological study. Egypt. J. Occup Med., 10, 247-258.

Wilson, G.S. and Miles, A.A. (1985): Topley and Wilson, s principles of bacteriology and immunity. $6^{\text {th }}$ Edition, Eward and Aronld, Publishers LTD, London, UK. 